\title{
KAPASITAS VITAL PARU PADA PENDUDUK DATARAN TINGGI DESA RURUKAN TOMOHON
}

\author{
${ }^{1}$ Juarfianti \\ ${ }^{2}$ Joice N. A. Engka \\ ${ }^{2}$ Siantan Supit \\ ${ }^{1}$ Kandidat Skripsi Bagian Fisika Kedokteran Universitas Sam Ratulangi Manado \\ ${ }^{2}$ Bagian Fisiologi Fakultas Kedokteran Universitas Sam Ratulangi Manado \\ Email: Juarfianti.arfah@gmail.com
}

\begin{abstract}
Breath is inspiring air from outside and expiring air out of the body. Lung vital capacity is the maximum amount of air that can be expired from the lungs (approximately $4600 \mathrm{ml}$ ). The value of vital lung capacity of adult males is $20-25 \%$ higher than of adult females. Some studies have shown that there are many factors influencing the lung vital capacity. This study aimed to describe lung vital capacity among plateu population of Rurukan Tomohon village. This was a descriptive analytic cross sectional study. Subjects were 30 people, aged 20-70 years old, who lived in Rurukan plateu. The lung vital capacity was measured by using a spirometer. Data were processed and presented as distribution frequency tables. The results showed that the majority of respondents were over 40-50 years old (36.7\%), housewives (46.7\%), had index of obesity I (50\%), with the degree of restrictive lung vital capacity within normal limit (80\%). Conclusion: Most of the people living in Rurukan plateau had normal lung vital capacity.
\end{abstract}

Keywords: vital lung capacity, plateu

\begin{abstract}
Abstrak: Pernapasan adalah menghirup udara dari luar serta menghembuskan udara keluar dari tubuh. Kapasitas vital paru adalah jumlah udara maksimum yang dapat dikeluarkan dari paru (kira-kira $4600 \mathrm{ml}$ ). Nilai kapasitas vital paru pria dewasa lebih tinggi 20-25\% daripada wanita dewasa. Sejumlah penelitian menunjukkan bahwa banyak faktor yang mempengaruhi kapasitas vital paru. Penelitian ini bertujuan untuk mengetahui gambaran kapasitas vital paru pada penduduk dataran tinggi desa Rurukan Tomohon. Jenis penelitian ini bersifat deskriptif analitik dengan rancangan potong lintang. Subjek penelitian terdiri dari 30 orang berusia 2070 tahun yang tinggal di dataran tinggi. Data diperoleh melalui pengukuran kapasitas vital paru menggunakan spirometer. Data diolah dan disajikan dalam bentuk tabel distribusi frekuensi. Hasil penelitian menunjukkan bahwa mayoritas responden berusia $>40-50$ tahun (36,7\%), pekerjaan ibu rumah tangga (46,7\%), indeks massa tubuh obes I (50\%), dan derajat restriktif kapasitas vital paru normal (80\%). Simpulan: Sebagian besar penduduk dataran tinggi desa Rurukan mempunyai kapasitas vital paru normal.
\end{abstract}

Kata kunci : kapasitas vital paru, dataran tinggi.

Pernapasan adalah menghirup udara dari luar yang mengandung oksigen $\left(\mathrm{O}_{2}\right)$ ke dalam tubuh serta menghembuskan udara yang banyak mengandung karbondioksida $\left(\mathrm{CO}_{2}\right)$ sebagai sisa dari oskidasi keluar dari tubuh. Fungsi utama pernapasan adalah 
sebagai ventilasi paru, difusi oksigen dan karbondioksida antara alveoli dan darah, pengangkutan oksigen dan karbondioksida dalam darah dan cairan tubuh ke dan dari sel jaringan tubuh, serta pengaturan ventilasi dan hal-hal lain dari pernapasan. ${ }^{1}$

Fungsi paru-paru yang dapat diukur adalah kapsitas inspirasi, kapasitas residu fungsional, kapasitas vital dan kapsitas paru total. Kapasitas vital paru adalah jumlah udara maksimum yang dapat dikeluarkan seseorang dari paru, setelah terlebih dahulu mengisi paru secara maksimum dan kemudian mengeluarkan sebanyak-banyaknya (kira-kira 4600 militer). Alat yang digunakan untuk mengukur kapasitas vital paru adalah spirometer. $^{2}$

Udara bergerak masuk dan keluar karena ada selisih tekanan yang terdapat antara atmosfir dan alveolus akibat kerja mekanika otot-otot. Dinding toraks berfungsi sebagai penembus. Selama inspirasi, volume toraks bertambah besar karena diafragma turun dan iga terangkat akibat kontraksi beberapa otot yaitu sternokleidomastoiseus mengangkat sternum ke atas dan otot seratus, skalenus dan interkostalis eksternus mengangkat igaiga. ${ }^{3}$

Pada keadaan beristirahat normal, difusi dan keseimbangan oksigen di kapiler darah paru-paru dan alveolus berlangsung kira-kira 0,25 detik dari total waktu kontak selama 0,75 detik. Hal ini menimbulkan kesan bahwa paru-paru normal memiliki cukup cadangan waktu difusi. Pada beberapa penyakit misak fibrosis paru, udara dapat menebal dan difusi melambat sehingga ekuilibrium mungkin tidak lengkap, terutama sewaktu berolahraga dimana waktu kontak total berkurang. Jadi, blok difusi dapat mendukung terjadinya hipoksemia, tetapi tidak diakui sebagai faktor utama. ${ }^{4}$

Pertukaran oksigen dan karbondioksida antara darah dan udara berlangsung di alveoli paru-paru. Pertukaran tersebut diatur oleh kecepatan dan di dalamnya aliran udara pernapasan, dan tergantung pada difusi oksigen dari alveoli ke dalam darah kapiler dinding alveoli. Hal yang sama juga berlaku untuk gas dan uap yang dihirup. Paru-paru merupakan jalur masuk terpenting dari bahan-bahan berbahaya lewat udara dan paparan kerja. ${ }^{3,5}$ Penelitian ini bertujuan untuk mengetahui kapasitas vital paru pada penduduk dataran tinggi desa Rurukan Tomohon.

\section{METODE PENELITIAN}

Penelitian ini bersifat deskriptif analitik dengan rancangan potong lintang dan dilaksanakan pada bulan November Desember 2013. Pengambilan sampel dilakukan di desa Rurukan Tomohon. Subjek penelitian ini penduduk yang tinggal di desa Rurukan Tomohon, dengan kriteria inklusi tidak merokok, berjenis kelamin perempuan, berusia 20 - 70 tahun dan tidak menderita penyakit saluran pernapasan. Kriteria eksklusi yaitu menderita penyakit saluran pernapasan, seperti asma, TBC, influenza, pneumonia, dll. Variabel penelitian ini antara lain kapasitas vital paru dan dataran tinggi.

\section{HASIL PENELITIAN}

Jumlah subjek yang di teliti sebanyak 30 orang penduduk yang tinggal di dataran tinggi di desa Rurukan Tomohon.

Tabel 1 menunjukkan usia subjek penelitian terbanyak $>40-50$ tahun dengan jumlah 11 orang (36,7\%).

Tabel 1. Distribusi subjek berdasarkan usia

\begin{tabular}{cccc}
\hline $\begin{array}{c}\text { Usia } \\
\text { (Tahun) }\end{array}$ & N & $\%$ & KV \\
\hline $20-30$ & 1 & 3,3 & 110 \\
$31-40$ & 7 & 23,3 & 92,9 \\
$41-50$ & 11 & 36,7 & 99,8 \\
$51-60$ & 7 & 23,3 & 94,3 \\
$61-70$ & 4 & 13,3 & 94,4 \\
\hline
\end{tabular}

Tabel 2 menunjukkan pekerjaan subjek penelitian terbanyak ialah ibu rumah tangga (IRT) dengan jumlah 14 orang (46,7\%). Tabel 3 menunjukkan indeks massa tubuh (IMT) subjek penelitian dengan distribusi terbanyak pada obes I dengan jumlah 15 orang (50\%). 
Tabel 2. Distribusi subjek berdasarkan pekerjaan

\begin{tabular}{cccc}
\hline Pekerjaan & $\mathrm{N}$ & $\%$ & $\mathrm{KV}$ \\
\hline IRT & 14 & 46,7 & 93,9 \\
Petani & 11 & 36,7 & 104,7 \\
Pensiunan & 1 & 3,3 & 94 \\
PNS & 1 & 3,3 & 66 \\
Swasta & 3 & 10 & 89,7 \\
\hline
\end{tabular}

Tabel 4 menunjukkan tentang distribusi frekuensi responden berdasarkan derajat restriktif kapasitas vital paru sesuai pada hasil pemeriksaan kapasitas vital paru. Paling banyak dengan nilai normal $(>80)$ dengan jumlah 24 orang (80\%), diikuti dengan nilai ringan ( $60-80)$ dengan jumlah 5 orang $(16,7 \%)$ dan yang paling sedikit dengan nilai sedang ( $50-59$ ) dengan jumlah 1 orang (3,3\%). Tidak ada subjek penelitian yang memiliki niai berat ( $<40)$.

Tabel 3. Distribusi subjek berdasarkan indeks massa tubuh

\begin{tabular}{ccccc}
\hline IMT & Kategori & $\mathrm{n}$ & $\%$ & $\mathrm{KV}$ \\
\hline$<18,5$ & Underweight & 0 & 0 & 0 \\
$18,5-22,9$ & Normal & 5 & 16,7 & 106,2 \\
$\geq 23,0$ & Overweight & - & - & - \\
$23,0-24,9$ & Berisiko obes & 5 & 16,7 & 100,3 \\
$25,0-29,9$ & Obes I & 15 & 50 & 93 \\
$\geq 30,0$ & Obes II & 5 & 16,7 & 93,6 \\
\hline
\end{tabular}

Tabel 4. Distribusi frekuensi berdasarkan derajat kapasitas vital paru

\begin{tabular}{cccc}
\hline Tipe restriktif KV (\%) & $\mathrm{n}$ & $\%$ & KV \\
\hline Normal $(>80)$ & 24 & 80 & 103 \\
Ringan $(60-80)$ & 5 & 16,7 & 73,8 \\
Sedang $(50-59)$ & 1 & 3,3 & 54 \\
Berat $(<40)$ & 0 & 0 & 0 \\
\hline
\end{tabular}

\section{BAHASAN}

Berdasarkan hasil penelitian dapat diketahui bahwa mayoritas responden di desa Rurukan Tomohon berusia $>40-50$ tahun sebanyak 11 responden (36,7\%). Usia termuda 20 tahun sedangkan usia tertua 70 tahun.

Faal paru seseorang dipengaruhi oleh umur. Secara fisiologis dengan bertambahnya umur maka kemampuan organ-organ tubuh akan mengalami penurunan secara alamiah, termasuk dalam hal ini adalah gangguan fungsi paru. Terjadi penurunan fungsi paru setelah usia 30 tahun, dimana setiap tahun luas permukaan paru akan berkurang 4\%. Umur merupakan variabel yang penting dalam hal terjadinya gangguan fungsi paru. Semakin bertambahnya umur terutama disertai dengan kondisi lingkungan yang buruk serta kemungkinan terkena suatu penyakit, maka kemungkinan terjadinya penurunan fungsi paru dapat terjadi lebih besar.,

Menurut suatu teori, semakin tua umur seseorang maka semakin besar kemungkinan terjadinya penurunan fungsi paru. Hal ini didukung dengan penelitian sebelumnya, bahwa semakin bertambah usia maka akan dapat menurunkan kapasitas vital paru seseorang. ${ }^{8,9}$

Riwayat pekerjaan terpapar debu dapat menyebabkan gangguan paru. Semakin lama seseorang bekerja di suatu daerah berdebu maka kapasitas paru seseorang akan semakin menurun. Pekerja yang berada pada lingkungan kerja dengan kadar debu tinggi dalam waktu lama memiliki risiko tinggi terkena obstruksi paru. ${ }^{10}$ 
Hal ini di dukung dengan penelitian Irvan $^{11}$ bahwa semakin lama seseorang terpapar debu berbahaya makan semakin besar kemungkinan terjadinya gangguan pernapasan. Apabila kondisi paru terpapar dengan berbagai komponen tercemar, fungsi fisiologis paru sebagai organ utama pernapasan akan mengalami berbagai gangguan.

Kesehatan dan daya kerja erat hubungannya dengan status gizi seseorang. Secara umum kekurangan gizi akan berpengaruh terhadap kekuatan daya tahan dan respon imunologis terhadap penyakit dan keracunan. Status gizi juga berperan terhadap kapasitas paru. Orang dengan postur kurus biasanya kapasitas vital paksanya lebih besar dari orang dengan postur gemuk. Status gizi merupakan keadaan tubuh sebagai akibat konsumsi makanan dan zat gizi. Salah satu akibat dari kekurang gizi adalah dapat menurunkan sistem imunitas dan antibodi sehingga orang mudah terserang infeksi seperti pilek, batuk, diare dan juga berkurangnya kemampuan tubuh untuk melakukan detoksifikasi terhadap benda asing seperti debu yang masuk dalam tubuh.

Meningkatnya jumlah lemak di dinding dada dan abdomen, kemungkinan mempunyai efek pada sifat mekanik dada dan diafragma serta menunjukkan adanya perubahan fungsi pernapasan. Hal ini menurunkan volume paru dan perubahan gambaran ventilasi pada setiap respirasi. Selanjutnya, peningkatan jumlah massa lemak menunjukkan compliance sistem pernapasan secara luas dan pengurangan yang lebih besar dapat dilihat pada dinding dada dari paru. Penimbunan massa lemak ini menunjukkan elastisitas dan kemampuan sistem pernapasan, sehingga otot-otot pernapasan bekerja keras guna mengatasi rekoil elastis yang berlebihan. Jadi pada obesitas, compliance dinding dada dan abdomen menurun, kerja pernapasan meningkat dan volume residu pernapasan serta kapasitas vital paru menurun. ${ }^{12}$

Berdasarkan hasil penelitian, mayoritas responden memiliki nilai kapasitas vital paru yang normal tetapi ada sekitar 6 orang yang mengalami gangguan fungsi paru restriktif ringan dan sedang. Restriksi adalah suatu kondisi dimana volume maksimum yang di capai paru telah berkurang. Proses gangguan fungsi paru restriktif dimulai sebagai peradangan interstisial yang terutama mengenai septa (alveolitis interstisial), ditandai dengan kekacauan paru atau keduanya akibat menurunnya compliance dan semua volume paru termasuk kapasitas vital paru. ${ }^{14}$

Pada gangguan restriktif, partikel debu berukuran $<5$ mikron akan masuk ke dalam alveoli dan membentuk fokus serta berkumpul di bagian awal saluran limfe paru. Debu ini akan di fagositosis oleh makrofag menyebabkan terjadinya autolisis. Makrofag yang lisis merangsang terbentuknya makrofag baru. Makrofag baru memfagositosis sehingga terjadi lagi autolisis, keadaan ini terjadi berulangulang. Pembentukan dan destruksi makrofag yang terus menerus berperan penting pada pembentukan jaringan ikat kolagen dan pengendapan hialin pada jaringan ikat tersebut. Fibrosis ini terjadi pada parenkim paru, yaitu pada dinding alveoli dan jaringan interstisial. Akibat fibrosis, paru menjadi kaku sehingga menimbulkan gangguan pengembangan paru yaitu kelainan fungsi paru yang restriktif. $^{3}$

Pada keadaan restriksi terjadi penurunan compliance atau daya pengembangan paru. Hal ini juga didukung oleh faktor intrinsik seperti kebiasaan berolahraga. Seseorang yang tidak pernah berolahraga akan menyebabkan peredaran darah dalam paru tidak lancar. Akibatnya daya pengembangan paru mengalami penurunan.

\section{SIMPULAN}

Dari hasil penelitian yang dilakukan pada penduduk yang tinggal di dataran tinggi desa Rurukan Tomohon dapat disimpukan bahwa sebagian besar mempunyai nilai kapasitas vital paru normal. 


\section{SARAN}

Perlu dilakukan penelitian serupa dengan sampel yang lebih banyak untuk mendapatkan hasil yang lebih bermakna. Juga perlu dilakukan penelitian dengan membandingkan kapasitas vital paru antara dataran tinggi dan dataran rendah.

\section{DAFTAR PUSTAKA}

1. Guyton \& Hall.Ventilasi Paru. Guyton AC, Hall JE. Buku Ajar Fisiologi Kedokteran. Edisi ke-11. Jakarta: Penerbit Buku Kedokteran EGC; 2010. p. 495-99.

2. Sirait M. Hubungan Karakteristik Pekerja dengan Faal Paru di Kilang Padi Kecamatan Porsea. 2010 [cited 2013 Sep 3]. Available from: http://respiratory.usu.ac.id/bitstream/1 23456789/17738/4/chapter\%2011.pdf

3. Price \& Wilson. Anatomi dan Fisioogi Sistem Pernapasan. Wilson LR. Patofisiologi: Konsep Klinis ProsesProses Penyakit. Edisi ke-6. Volume 2. Jakarta: Penerbit Buku Kedokteran EGC; 2010. p. 736-50.

4. Hastuti J. Ukuran dan Bentuk Dada Penduduk di Dataran Tinggi Sumigaluh dan Dataran Rendah Galur Kulon Progo Yogyakarta. 2012 [2013 Sep 3].

Available from:

http://jurnal.ugm.ac.id/index.php/jai/a rticle/view/1145

5. Zullies I. Anatomi dan Fisiologi Saluran Pernapasan. 2010 [2013 Sep 3].
Available

from: http://zulliesikawati.staff.ugm.ac.id/w p-content/uploads/an-physrespiratory-system.pdf

6. Neil MR, David D. Geriatric Medicine. Horrison's Principles of Internal Medicine. Edisi ke-16. New york: McGraw-Hill Book Company; 2005. p. 43-7.

7. Syaifuddin. Anatomi Fisiologi untuk Mahasiswa keperawatan. Edisi ke-3. Jakarta: Penerbit Buku Kedokteran EGC; 2006. p. 115-17.

8. Joko S. Occupational Disease. Deteksi Dini Penyakit Akibat Kerja. Jakarta: Penerbit Buku Kedokteran EGC; 1995. p. 90-5.

9. Siti MM. Hubungan Antara Masa Kerja, Pemakaian APD Pernapasan pada Tenaga Kerja Pengamplasan dengan Kapasitas Fungsi Paru PT. Ascent House Pencangan Jepara [skripsi]. Semarang: Universitas Negeri Semarang; 2006.

10.Achmadi UF.Upaya Kesehatan Kerja Sektor Informal di Indonesia. Jakarta: Departemen Kesehatan RI; 1994.

11.Irvan S. Hubungan Masa Kerja dengan Kapasitas Vital Paru Operator Empat Stasiun Pengisian Bahan Bakar Umum (SPBU) Kota Yogyakarta [skripsi]. Yogyakarta: Universitas Ahmad Dahlan; 2010.

12.Flier JS. Obesity. Diabetes Mellitus. Philadelphia: Lea and Febiger, Waverty Co; 1994. p. 351-62. 